\title{
PENERAPAN COOPERATIVE SCRIPT UNTUK MENINGKATKAN KEAKTIFAN SISWA KELAS VIII C SMP NEGERI 2 TEMON KULON PROGO Oleh: Langgeng Raharjo \\ SMP Negeri 2 Temon \\ Email: langgeng_raharjo@gmail.com
}

\begin{abstract}
Abstrak
Tujuan penelitian ini adalah untuk mengetahui implementtasi pembelajaran cooperative script dapat meningkatkan pemahaman dan meningkatkan keatifan siswa kelas VIII C SMP Negeri 2 Temon. Dengan menggunakan metode cooperative script diharapkan mengefektifkan pembelajaran khususnya pembelajaran IPS. Subyek penelitian ditujukan pada seluruh siswa kelas VIII C SMP N 2 Temon Kabupaten Kulon Progo. Penelitian ini menggunakan analisis secara diskripsi kualitatif dengan analisisnya menggunakan teknik analisis kritis model siklus melalui langkah: perencanaan, tindakan, pengamatan, dan refleksi. Teknik yang digunakan untuk mengumpulkan data meliputi pengamatan dan dokumen pre test dan post test tiap siklus. Pada kondisi siklus I hasil belajar siswa rendah, siswa yang mendapat nilai < 76 sebanyak 30 (93.75\%) siswa; nilai 76 -100 sebanyak 2 $(6.25 \%)$ siswa. Hasil post testnya siswa yang mendapat nilai < 76 sebanyak 19 (59.37\%); nilai 76 -100 sebanyak 13 (40.63\%) siswa. Ketuntasan hasil belajar pada siklus ini 13 (63.75\%) siswa dengan kondisi awalnya hanya $2(43.13 \%)$ siswa. Pada pre tes siklus II, siswa yang mendapat nilai < 76 sebanyak $28(87.50 \%)$ siswa; nilai 76-100 sebanyak $4(12.50 \%)$ siswa. Pada post testnya siswa yang mendapat nilai < 76 sebanyak 15 (46.88\%); nilai 76 -100 sebanyak $17(53.12 \%)$ siswa. Ketuntasan hasil belajar pada siklus ini 17 $(71.88 \%)$ siswa dengan kondisi awalnya hanya 4 (43.75\%) siswa. Skor keaktifan pra siklus secara keseluruhan adalah 49,61 \% dan ini masuk dalam kategori kurang aktif. Skor keaktifan siklus 1 secara keseluruhan adalah 57,52 \%. Keaktifan siklus 2 secara keseluruhan adalah 85,55 \% dan ini masuk dalam kategori sangat aktif. Berdasarkan hasil tersebut menunjukan penggunaan model cooperative script dapat manjadikan siswa lebih aktif dari pembelajaran sebelumnya, yakni pada siklus 2 menunjukan pada posisi sangat aktif.
\end{abstract}

Kata kunci: cooperative script, pembelajaran IPS, keaktifan siswa 


\begin{abstract}
The purpose of research was to determine implementation of cooperative script learning to improving the understanding and activities students of grade VIII C, SMP Negeri 2 Temon. Using the cooperative script method expected make learning effectively, especially in social studies subjects. The research subjects was all of students of class VIII C of SMP N 2 Temon, Kulon Progo. This study uses descriptive qualitative analysis with its analysis using the critical analysis technique of the cycle model through steps: planning, action, observation, and reflection. Techniques used to collect data include observations and pre-test and post-test documents for each cycle. In the condition of cycle I student learning outcomes are low, students who score <76 are 30 (93.75\%) students; grades $76-100$ by $2(6.25 \%)$ students. The post-test results of students who scored $<76$ were 19 (59.37\%); grades 76 -100 as many as 13 (40.63\%) students. Completeness of learning outcomes in this cycle 13 (63.75\%) students with the initial condition only 2 (43.13\%) students. In the pre-cycle II test, students who scored <76 were 28 (87.50\%) students; grades 76100 as many as 4 (12.50\%) students. In the post-test students who scored <76 were 15 (46.88\%); grades $76-100$ as many as 17 (53.12\%) students. Completeness of learning outcomes in this cycle 17 (71.88\%) students with initial conditions only 4 (43.75\%) students. The overall pre cycle activity score was $49.61 \%$ and this is in the less active category. The overall activity score of cycle 1 is $57.52 \%$. The overall activity of cycle 2 is $85.55 \%$ and this included in the very active category. Based on these results shows the use of cooperative script models can make students more active than previous learning, ie in cycle 2 shows the very active position.
\end{abstract}

Keywords: cooperative script, social studies learning, student activeness

\title{
Pendahuluan
}

Pembangunan di Indonesia antara lain diarahkan untuk meningkatkan kualitas sumber daya manusia (SDM) yang berkualitas. SDM yang berkualitas menjadi tumpuan utama bagi bangsa ini untuk berkompetisi dengan negara lain di era globalisasi ini. Berkaitan dengan itu pendidikan formal merupakan salah satu wadah dalam membangun SDM yang berkualitas. Pendidikan formal di Indonesia merupakan satu-satunya prasyarat yang harus 
dipenuhi dalam rangka menduduki salah satu jabatan dalam pemerintahan maupun swasta. Menurut Mohammad Nuh (2010) dalam sambutannya di buku Sejarah Perkembangan Kurikulum SMP menyatakan bahwa ciri utama dari pendidikan salah satunya adalah anticipative, artinya pengembangan potensi peserta didik harus diarahkan agar dia mampu menjawab persoalan ke depan. Agar anak didik nantinya mampu bersaing di dunia pemerintahan dan dunia usaha maka melalui pendidikan formal seharusnya mampu memproses, mencetak lulusan yang berkualitas tinggi. Out put yang berkualitas tidak lepas dari bagaimana mengemas pendidikan yang diminati anak untuk mempelajari suatu disiplin ilmu.

Kecenderungan anak didik sekarang adalah mengarah pada spesialisasi sesuai dengan keinginannya/kesukaannya. Padahal kelulusan itu tidak hanya ditentukan oleh satu mata pelajaran saja, namun semuanya didukung oleh beberapa disiplin ilmu atau bahkan semua saling mendukung. Salah satu pelajaran yang tidak disukai oleh siswa SMP adalah IPS. Dengan diberlakukannya IPS terpadu menjadikan beban belajar dan ilmu pengetahuan semakin berat. Dalam membangun SDM yang berkualitas tentunya IPS mempunyai kantribusi yang besar.

Mata pelajaran IPS perlu diberikan peserta didik mulai sejak dini agara peserta didik dapat menghayati suatu kejadian nasional dan internasional, mengetahui kekayaan alam dunia, mengetahui kondisi politik dan ekonomi dunia. Sehingga siswa dapat mencerna, berfikir, menanggapi permasalahan dan mampu memberikan solusi secara afektif dan psikomotorik yang dapat membentuk pola pikir dan perilaku manusia. Masalah pendidikan merupakan hal yang sangat komplek, ini berarti dalam pencapaian tujuan terdapat berbagai faktor yang mempengaruhi proses pendidikan, salah 
satunya adalah proses belajar mengajar yang melibatkan guru dan siswa.

Dengan motode yang lama banyak siswa yang memandang bahwa pembelajaran IPS di SMP Negeri 2 Temon sangat membosankan bukan hanya materi hafalan yang banyak namun juga karena metode pembelajaran yang digunakan yaitu metode konvensional dimana pembelajaran berpusat pada guru. Padahal dalam tujuan pembelajaran diharapkan siswa memahami terhadap yang dipelajari, sehingga dibutuhkan penerapan dan pengembangan model secara optimal agar mencapai hasil belajar yang diharapkan. Menurut Pardjono (2007:12) Urgensi dari penelitian tindakan kelas adalah guru merupakan agen of change yang harus selalu membuat perubahan dan peningkatan profesionalisme. Untuk itu perlu pembaharuan dalam metode pembelajaran khususnya IPS. Untuk itu, diharapkan melalui implementasi pembelajaran cooperative script siswa kelas VIII C SMP Negeri 2 Temon pada mata pelajaran IPS dapat meningkatkan pemahaman siswa.

\section{Pembelajaran IPS}

Pendidikan adalah usaha sadar dan terencana untuk mewujudkan suasana belajar dan proses pembelajaran agar peserta didik secara aktif mengembangkan potensi dirinya untuk memiliki kekuatan spiritual keagamaan, pengendalian diri, kepribadian, kecerdasan, akhlak mulia, serta keterampilan yang diperlukan dirinya, masyarakat, bangsa dan negara. Kegiatan belajar mengajar pada dasarnya mengembangkan kemampuan fisik dan psikis serta kemampuan penyesuaian social secarautuh (2010:126).

Menurut Winarno Surakhmat (Suyanto dan Djihad Hisyam: 81), dalam proses belajar mengajar hakekatnya meupakan proses edukatif, paling sedikit harus terdapat (1) tujuan yang jelas yang 
akan dicapai, (2) bahan yang menjadi interaksi, (3) siswa yang aktif mengalami, (4) guru yang melaksanakan, (5) metode tertentu untuk mencapai tujuan, (6) situasi yang memungkinkan proses interaksi berlangsung dengan baik, dan (7) evaluasi atau penilaian terhadap hasil interaksi itu. Jadi, proses belajar mengajar merupakan salah satu system interaksi edukatif yang amat menentukan keberhasilan peserta didik.

Tujuan utama para pendidik ialah membantu siswa untuk mengembangkan dirinya, yaitu membantu masing-masing individu untuk mengenal diri mereka sendiri sebagai manusia yang unik dan membantu dalam mewujudkan potensi-potensi yang ada pada diri mereka. Untuk itu pembelajaran harus mampu mengkombinasi unsur-unsur manusiawi, material, fasilitas, perlengkapan dan prosedur yang saling mempengaruhi untuk tujuan pembelajaran. Pada hakekatnya, meningkatkan kemampuan kognitif, afektif dan psikomotorik siswa yang dikembangkan melalui pengalaman belajar. Pembelajaran merupakan kegiatan memberi bantuan atau pertolongan kepada siswa agar memperoleh pengalaman, ketrampilan dan perubahan sikap atau tingkah laku setelah pembelajaran selesai.

IPS adalah salah satu mata pelajaran yang diberikan mulai SD sampai SMP yang mengkaji seperangkat peristiwa, fakta, konsep, dan generalisasi yang berkaitan dengan social. IPS adalah bahan kajian yang terpadu yang merupakan penyederhanaan, adaptasi, seleksi, dan modifikasi yang di organisasikan dari konsep-konsep dan ketrampilan-ketrampilan Sejarah, Geografi, Antropologi, dan Ekonomi. (Departemen Pendidikan Nasional, 2007: 14)

Pembelajaran IPS merupakan suatu proses kegiatan belajar mengajar antara siswa dengan guru tentang teori yang mengkaji seperangkat peristiwa, fakta, konsep, dan generalisasi yang 
berkaitan dengan sosial untuk mencapai tujuan pembelajaran. Tujuan itu antara lain meningkatkan kemampuan kognitif, afektif, dan psikomotor yang dikembangkan melalui pengalaman belajar. Jadi pembelajaran IPS tidak hanya menuntut siswa untuk menghafal dan memahami seluruh materi IPS.

\section{Metode Skrip Kooperatif}

Metode pembelajaran adalah metode yang kita gunakan pada materi ini adalah metode Skrip kooperatif. Skrip kooperatif adalah metode belajar dimana siswa bekerja berpasangan dan secara lisan mengikhtisarkan bagian-bagian dari materi yang dipelajari. Langkah-langkah metode kooperatif Skrip:

1. Guru membagi siswa untuk berpasangan.

2. Guru membagikan wacana/materi tiap siswa untuk dibaca dan membuat ringkasan.

3. Guru dan siswa menetapkan siapa yang pertama berperan sebagai pembicara dan siapa yang berperan sebagai pendengar.

4. Pembicara membacakan ringkasannya selengkap mungkin, dengan memasukkan ide-ide pokok dalam ringkasannya. Sementara pendengar menyimak / mengoreksi / menunjukkan ide-ide pokok yang kurang lengkap dan membantu mengingat/menghapal ide-ide pokok dengan menghubungkan materi sebelumnya atau dengan materi lainnya.

5. Bertukar peran, semula sebagai pembicara ditukar menjadi pendengar dan sebaliknya, serta lakukan seperti di atas.

6. Kesimpulan guru.

7. Penutup.

Kelebihan:

1. Melatih pendengaran, ketelitian / kecermatan.

2. Setiap siswa mendapat peran.

3. Melatih mengungkapkan kesalahan orang lain dengan lisan. 
JIPSINDO No. 2, Volume 6, September 2019

Kekurangan:

1. Hanya digunakan untuk mata pelajaran tertentu.

2. Hanya dilakukan dua orang (tidak melibatkan seluruh kelas sehingga koreksi hanya sebatas pada dua orang tersebut).

\section{Hasil Belajar}

Prestasi belajar adalah keberhasilan yang dicapai dalam belajar dan dapat ditunjukan dengan adanya perubahan tingkah laku yang mengasah pada penguasaan pengetahuan, kecakapan dan kebiasaan serta sikap, berkat pengalaman dan latihan. Prestasi belajar dapat dilihat melalui suatu nilai yang di dapat siswa dalam mengerjakan sesuatu pada saat tertentu. Menurut Susilo (2007: 80) tujuan penilaian adalah untuk mengetahui apakah siswa telah atau belum mengasai suatu kompetensi dasar tertentu, sedangkan menurut buku sejarah perkembangan kurikulum. Penilaian hasil belajar adalah upaya pengumpulan informasi untuk mengetahui seberapa jauh pengetahuan dan kemampuan telah dicapai oleh siswa pada akhir pembelajaran (2010:126).

\section{Aktivitas Belajar}

Menurut Dr. Vernon A Magnesen mengatakan "kita belajar: 10\% dari kita baca, 20\% dari yang kita dengar, 30\% dari apa yang kita lihat, 50\% dari apa yang kita lihat dan dengat, 70\% dari apa yang kita katakana, 90\% dari apa yang kita katakan dan lakukan (Bobi de Potter dkk, 2002:57). Proses kegiatan belajar mengajar yang baik salah satunya ditandai dengan adanya interaksi antara siswa dengan sesamanya, antara siswa dengan guru sehingga dapat 
JIPSINDO No. 2, Volume 6, September 2019

terjadi komunikasi yang baik di dalam kelas. Dengan adanya komunikasi yang baik di kelas diharapkan dapat memberikan dampak positif bagi siswa. Dampak positif yang diharapkan dari komunikasi yang baik antara lain:

1. Siswa berani untuk mengajukan pertanyaan

2. Siswa dapat mengemukakan dan mempertahankan pendapatnya dengan baik

3. Siswa berani menjawab pertanyaan, baik pertanyaan dari guru atau dari siswa lain.

4. Siswa teliti dalam menganalisis dan mengkaji suatu masalah

5. Siswa dapat mengambil keputusan

6. Siswa dapat menarik suatu kesimpulan dari suatu masalah.

Menurut Sardiman AM (2010: 101) aktivitas belajar :

1) Visual activities (membaca, memperhatikan),

2) Oral activities (menyatakan, merumuskan, bertanya, diskusi, wawancara),

3) Listening activities (mendengarkan petunjuk, mendengarkan pendapat orang lain),

4) Writing activities (menuliskan laporan, menyalin, membuat rangkuman),

5) Drawing activities (menggambar, membuat table, membuat grafik),

6) Motor activities (melakukan percobaan, kontruksi, bermain),

7) Mental activities (menanggapi, mengingat, menganalisis, memecahkan soal, mengambil keputusan),

8) Emotional activities (berminat, semangat, gembira, berani).

\section{Metode Penelitian}


Penelitian ini menggunakan penelitian tindakan kelas (PTK). Untuk itu desain penelitian lebih bersifat diskriptif. Penelitian tentang pembelajaran Model cooperative script mengkaji perubahan hasil belajar juga mengkaji aktivitas dan kefektifan model tersebut. Rancangan penelitian ini meliputi perencanaan, tindakan, observasi dan refleksi yang direncanakan selama 2 periode/siklus:

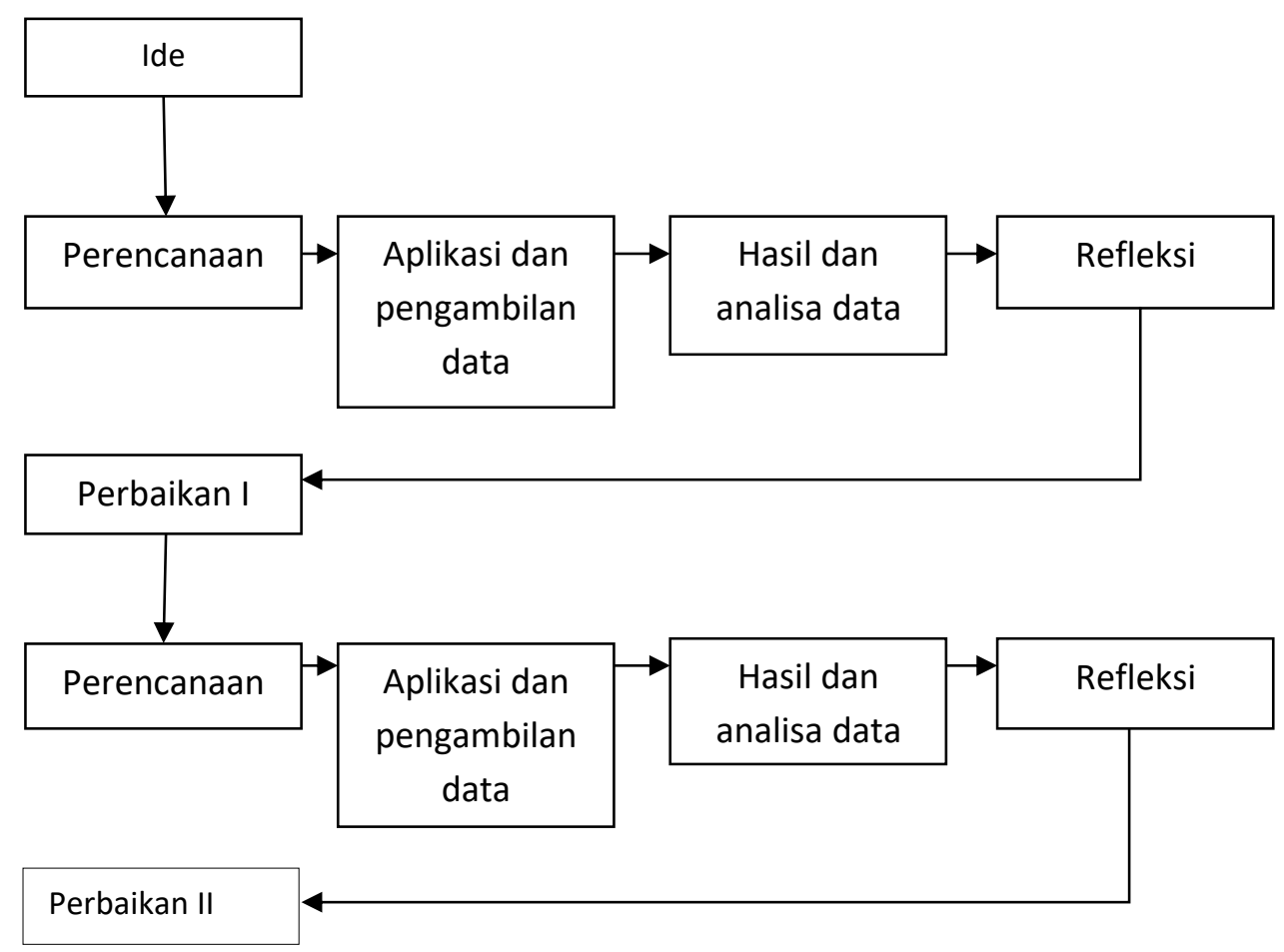

Gambar 1. Rancangan penelitian tindakan kelas

Dengan berpedoman pada refleksi awal, maka prosedur pelaksanaan penelitian tindakan kelas ini meliputi: perencanaan, pelaksanaan tindakan, observasi dan refleksi dalam setiap siklus.

1. Perencanaan

Kegiatan ini meliputi:

a. Peneliti dan guru pengajar menetapkan alternative upaya peningkatan kualitas pembelajaran.

b. Secara bersama-sama tim peneliti dan guru pengajar mata pelajaran membuat perencanaan pembelajaran. 
c. Melakukan latihan bersama guru pengajar dan tim peneliti, serta mendiskusikan tentang pembelajaran.

d. Membuat dan melengkapi alat media pembelajaran, seperangkat alat evaluasi seperti membuat lembar observasi bentuk tugas dll.

e. Menyiapkan segala perangkat observasi demi kesuksesan kegiatan penelitian yang dilengkapi pula dengan membuat lembar observasi, lembar wawancaradan catatan bebas.

2. Pelaksanaan Tindakan Pembelajaran

Kegiatan yang dilakukan pada tahap ini adalah melaksanakan pembelajaran sebagaimana yang telah direncanakan, yakni melaksanakan pembelajaran berikut proses evaluasi dengan menggunakan berbagai alat evaluasi yang telah dipersiapkan sebelumnya. Kegiatan ini juga memberikan kesempatan pada siswa untuk berpartisipasi dalam melaksanakan penilaian proses terhadap kinerja temannya selama pembelajaran.

3. Observasi

Observasi atau pengamatan merupakan suatu teknik atau cara mengumpulkan data dengan jalan mengadakan pengamatan terhadap kegiatan yang sedang berlangsung. Dalam tahap ini diolaksanakan observasi terhadap pelaksanaan pembelajaran dengan menggunakan lembar observasi yang telah dipersiapkan oleh tim peneliti dan pemegang mata pelajaran. Observasi ini dilaksanakan pada saat maupun setelah proses pembelajaran berlangsung. pada kegiatan ini digunakan lembar 
observasi yang dilengkapi dengan angket pedoman wawancara dan catatan bebas.

4. Refleksi

Data-data yang diperoleh melalui observasi dianalisis pada tahap ini. Berdasarkan hasil observasi peneliti bersama guru Pembina mata pelajaran dapat merefleksikan diri tentang kegiatan pembelajaran yang telah dilakukan. Berdasarkan hasil refleksi ini akan dapat diketahui kelemahan kegiatan pembelajaran yang telah dilakukan, sehingga dapat digunakan untuk menentukan tindakan kelas pada siklus berikutnya. Demikian seterusnya sampai tercapai target.

\section{Subyek Penelitian}

Subyek penelitian ditujukan pada seluruh siswa kelas VIII C SMP N 2 Temon Kabupaten Kulon Progo. Metode yang digunakan guru sebelumnya adalah ceramah yang membuat siswa menajadi bosan. Dengan menggunakan metode cooperative script diharapkan mengefektifkan pembelajaran khususnya pembelajaran IPS. Pengumpulan data bermaksud mendapatkan bahan yang relevan, akurat dan sesuai dengan tujuan penelitian. Metode yang digunakan untuk mengumpulkan data dalam penelitian ini adalah tes, observasi dan dokumentasi. Penelitian ini menggunakan analisis secara diskripsi kualitatif yaitu menggambarkan keadaan dilapangan secara diskripsi guna mengetahui kualitas dan efektifitas penggunaan metode pembelajaran.

\section{Hasil Penelitian}

Pada penelitian tindakan ini dilaksanakan dalam 2 siklus, dimana setiap siklusnya terdiri atas kegiatan Perencanaan, pelaksanaan, Pengamatan dan Refleksi. 
Siklus 1: KD 5.2. Mendeskripsikan peristiwa-peristiwa sekitar proklamasi dan proses terbentuknya negara kesatuan Republik Indonesia, yaitu pada peristiwa Rengasdengklok dan Kronologi proklamasi kemerdekaan Indonesia selama 2 x 40 menit ( 1 pertemuan )

Siklus 2: KD 5.2. Mendeskripsikan peristiwa-peristiwa sekitar proklamasi dan proses terbentuknya negara kesatuan Republik Indonesia, yaitu pada penyebaran berita proklamasi sampai dukungan beberapa daerah selama 2 x 40 menit ( 1 pertemuan )

\section{Pertemuan $I$.}

a. Pendahuluan

- Berdoa (contoh nilai yang ditanamkan: taqwa).

- Mengecek kehadiran siswa (contoh nilai yang ditanamkan: disiplin).

- Menanyakan kabar siswa - dengan fokus pada mereka yang tidak datang dan/atau yang pada pertemuan sebelumnya tidak datang (contoh nilai yang ditanamkan: peduli, empati).

- $\quad$ Apersepsi: apakah rengas dengklok itu?

- Motivasi:

- Bagaimanakah Indonesia merdeka?”.

- Guru menginformasikan tujuan pembelajaran.

b. Kegiatan inti

- Peserta didik mendengarkan penjelasan dari guru tentang peristiwa nagasaki dan hirosima .

- Siswa diberikan tugas mengerjakan tugas sebagai pre tes.

- Guru membuat konsep berfikir mempelajari materi ini (peristiwa seputar Proklamasi).

- Siswa dibagi dua kelompok menurut tempat duduk. 
- Guru memberikan tugas pada setiap siswa di dua kelompok.

- Satu kelompok mencari informasi dan menghafalkan tentang rengas dengklok dan kelompok lain tentang Kronologi proklamasi kemerdekaan Indonesia .

- Setiap anggota kelompok mencari satu orang kelompok lain.

- Kedua anggota tersebut saling bergantian memberikan informasi. Ketika yang satu cerita yang lain mencatat hal yang dirasa penting.

- Guru memberikan penguatan dan bersama siswa menyimpulkan hasil kegiatan diatas.

- Siswa diberikan tugas mengerjakan tugas sebagai pos tes.

c. Penutup

- Guru bersama siswa menyimpulkan pelajaran

- Penilaian

- Refleksi : Peserta didik mengungkapkan kesan terhadap pentingnya mengetahui terbentuknya RI.

- Guru menginformasikan kepada peserta didik bahwa pertemuan berikutnya untuk meringkas dan menghafal tentang peristiwa heroik setelah kemerdekaan Indonesia (contoh nilai yang ditanamkan: kemandirian dan usaha keras).

- Berdoa (contoh nilai yang ditanamkan: taqwa).

- Keluar kelas dengan tertib pada waktunya (contoh nilai yang ditanamkan: tertib, disiplin)

\section{Pertemuan II}

a. Pendahuluan

- Berdoa (contoh nilai yang ditanamkan: taqwa). 
- Mengecek kehadiran siswa (contoh nilai yang ditanamkan: disiplin).

- Menanyakan kabar siswa - dengan fokus pada mereka yang tidak datang dan/atau yang pada pertemuan sebelumnya tidak datang (contoh nilai yang ditanamkan: peduli, empati).

- Apersepsi : menampilkan bendera Keraton Yogyakarta.

- Motivasi : yang mampu memberi informasi yang beda dan bermutu mendapat nilai nilai lebih.

- Guru menginformasikan tujuan pembelajaran tentang Dukungan dari berbagai daerah berupa dukungan spontan dan tindakan heroik dari berbagai daerah

b. Kegiatan inti

- Guru membuat konsep berfikir mempelajari materi ini (penyebaran berita proklamasi KEMRI).

- Siswa diberikan tugas mengerjakan tugas sebagai pre tes.

- Siswa dibagi dua kelompok menurut tempat duduk.

- Guru memberikan tugas pada setiap siswa di dua kelompok.

- Satu kelompok mencari informasi dan menghafalkan tentang penyebaran berita proklamasi Kemerdekaan RI dan sidang PPKI berserta dukungan Kem-RI.

- Setiap anggota kelompok mencari satu orang kelompok lain.

- Kedua anggota tersebut saling bergantian memberikan informasi. Ketika yang satu cerita yang lain mencatat hal yang dirasa penting.

- Guru memberikan penguatan dan bersama siswa menyimpulkan hasil kegiatan diatas.

- Siswa diberikan tugas mengerjakan tugas sebagai pos tes. 


\section{c. Penutup}

- Guru dan Peserta didik membuat kesimpulan.

- Penilaian

- Refleksi : Peserta didik menyimpulkan Dukungan dari berbagai daerah berupa dukungan spontan dan tindakan heroik dari berbagai daerah.

- Guru menginformasikan kepada peserta didik bahwa pertemuan berikutnya adalah UH 1 di semester genap ini.

- Berdoa (contoh nilai yang ditanamkan: taqwa).

- Ke luar kelas dengan tertib pada waktunya (contoh nilai yang ditanamkan: tertib, disiplin).

Seperti pada pelaksanaan tersebut diatas Pre tes dilakukan pada kondisi awal (sebelum belajar dengan metode cooperative script). Sedangkan post tes diberikan pada siswa setiap selesai pembelajaran dengan tujuan untuk mengetahui hasil belajar siswa. Data skor pre tes siswa yang dilakukan sebelum pembelajaran menggunakan metode cooperative script dapat dilihat pada table berikut:

Tabel 2. Hasil Belajar Siswa dalam PBM

\begin{tabular}{|l|l|c|c|}
\hline \multicolumn{2}{|c|}{ Nilai Siswa } & $76-100$ & $<76$ \\
\hline Siklus I & Pre tes & $6.25 \%$ & $93.75 \%$ \\
\hline & Pos tes & $40.63 \%$ & $59.37 \%$ \\
\hline Siklus II & Pre tes & $12.50 \%$ & $87.50 \%$ \\
\hline & Pos tes & $53.12 \%$ & $46.88 \%$ \\
\hline
\end{tabular}

Sumber : Data penelitian (hasil pre tes dan pos tes) yang diolah 


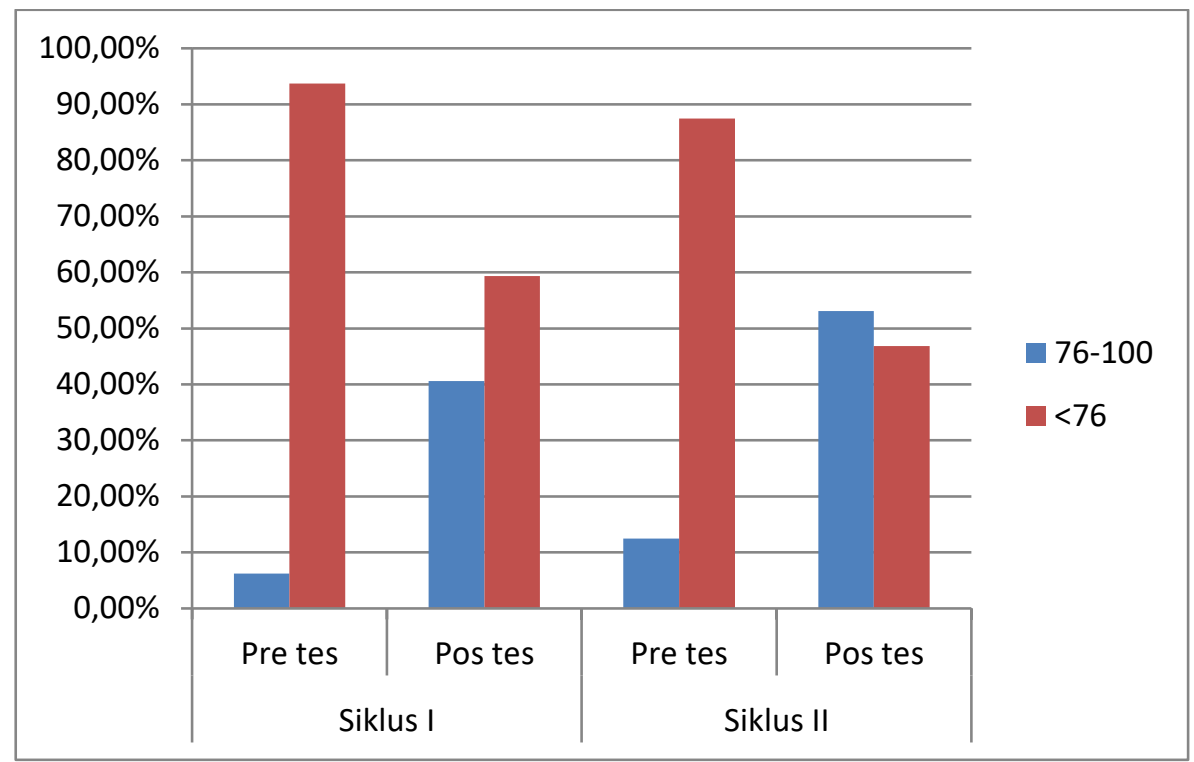

Grafik 1 . Perbandingan kondisi awal siswa dengan hasil belajar siswa setelah diberi perlakukan.

Dari table diatas menunjukkan hasil belajar IPS siswa. Pada kondisi awal (prêt tes) siklus I hasil belajar siswa rendah, siswa yang mendapat nilai < 76 sebanyak 30 (93.75\%) siswa; siswa yang mendapat nilai 76 -100 sebanyak 2 (6.25\%) siswa. Setelah menggunakan pembelajaran metode cooperative script hasil belajar dan aktifitas siswa meningkat. Sehingga siswa yang mendapat nilai < 76 sebanyak 13 (40.63\%) siswa; siswa yang mendapat nilai 76 100 sebanyak 19 (59.37\%) siswa. Ketuntasan hasil belajar pada siklus ini 63.75\% siswa dengan kondisi awal hasil belajarnya 43.13\%. Melihat dari kondisi hasil belajar pada siklus ini, perlu dilakukan refleksi untuk meningkatkan hasil belajar pada pembelajaran atau siklus selanjutnya.

Pada pre tes siklus II, siswa yang mendapat nilai < 76 sebanyak 28 (87.50\%) siswa; siswa yang mendapat nilai 76-100 sebanyak $4(12.50 \%)$ siswa. Setelah menggunakan pembelajaran metode cooperative script hasil belajar dan aktifitas siswa meningkat. Sehingga siswa yang mendapat nilai $<76$ sebanyak 15 
(46.87\%) siswa; siswa yang mendapat nilai 76 -100 sebanyak 17 (53.13\%) siswa. Ketuntasan hasil belajar pada siklus ini $71.88 \%$ siswa dengan kondisi awal hasil belajarnya 43.75\%. Melihat dari ketuntasan hasil belajar pada siklus ini cukup tinggi maka dihentikan atau tidak dilanjutkan. Dengan adannya peningkatan hasil belajar di setiap siklusnya, maka dapat dikatakan pembelajaran metode cooperative script dapat meningkatkan hasil belajar siswa pada matapelajaran IPS.

Dari hasil observasi, diperoleh data keaktifan siswa pada awal sebelum pembelajaran metode cooperative script dan setelah penerapan model ini, dapat dilihat pada table berikut:

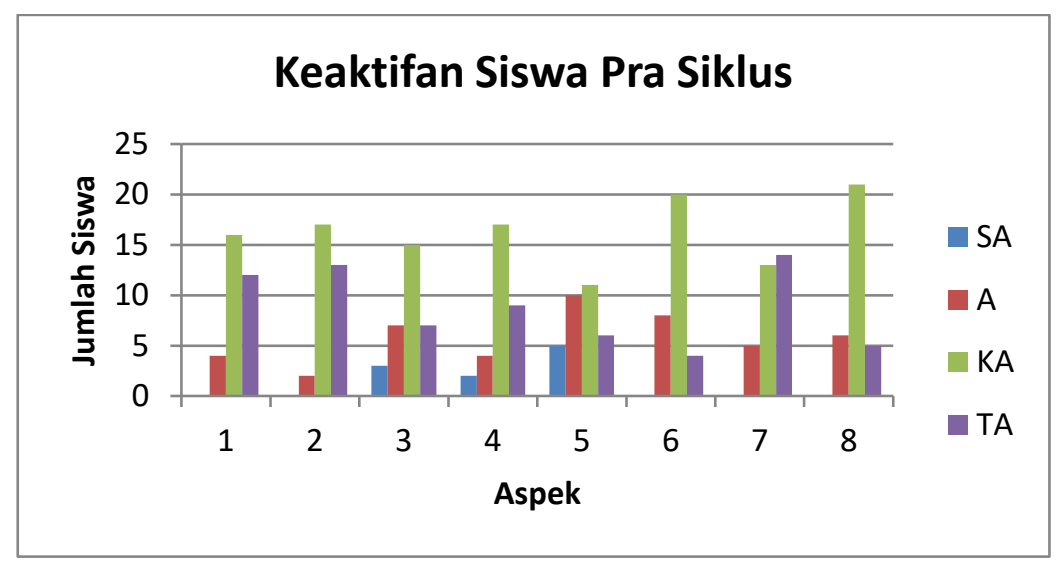

Grafik 2 . Perbandingan kondisi pada pra siklus

Dari hasil tersebut dapat dilihat bahwa:

1. Keseriusan siswa : $\mathrm{SA}=$ tidak ada $(0 \%), \mathrm{A}=4$ siswa $(12,5 \%)$, $\mathrm{KA}=16$ Siswa $(50 \%), \mathrm{TA}=12$ Siswa $(37,5 \%)$

2. Inisiatif bertanya siswa $: \mathrm{SA}=$ tidak ada $(0 \%), \mathrm{A}=2$ siswa $(6,25 \%), K A=17$ Siswa $(53,13 \%), T A=13$ Siswa $(40,62 \%)$

3. Partisipasi siswa dalam pembelajaran: $\mathrm{SA}=3$ siswa $(9,38 \%)$, $\mathrm{A}=7$ siswa $(21,87 \%), \mathrm{KA}=15$ Siswa $(46,88 \%), \mathrm{TA}=7$ Siswa $(21,87 \%)$

4. Kemampuan siswa menjelaskan konsep dengan kata-kata sendiri $: \mathrm{SA}=2$ siswa $(6,25 \%), \mathrm{A}=4$ siswa $(12,5 \%), \mathrm{KA}=17$ Siswa $(53,13 \%), \mathrm{TA}=9$ Siswa $(28,12 \%)$ 
5. Berdiskusi : $\mathrm{SA}=5$ siswa $(15,63 \%), \mathrm{A}=10$ siswa $(31,25 \%), \mathrm{KA}$ $=11$ Siswa $(34,37 \%), \mathrm{TA}=6$ Siswa $(18,75 \%)$

6. Kemampuan siswa memahami perintah guru : $\mathrm{SA}=0$ siswa (0\%), $A=8$ siswa (25\%), KA = 20 Siswa (62,5\%), TA = 4 Siswa $(12,5 \%)$

7. Kemampuan siswa menyimak cerita dari teman : $\mathrm{SA}=0$ siswa (0\%), A = 5 siswa $(15,63 \%), \mathrm{KA}=13$ Siswa $(40,62 \%), \mathrm{TA}=14$ Siswa $(43,75 \%)$

8. Kemampuan siswa membuat catatan penting : $\mathrm{SA}=0$ siswa (0\%), $A=6$ siswa $(18,75 \%), K A=21$ Siswa $(65,63 \%), T A=5$ Siswa $(15,62 \%)$

Skor keaktifan pra siklus secara keseluruhan adalah 49,61\% dan ini masuk dalam kategori kurang aktif.

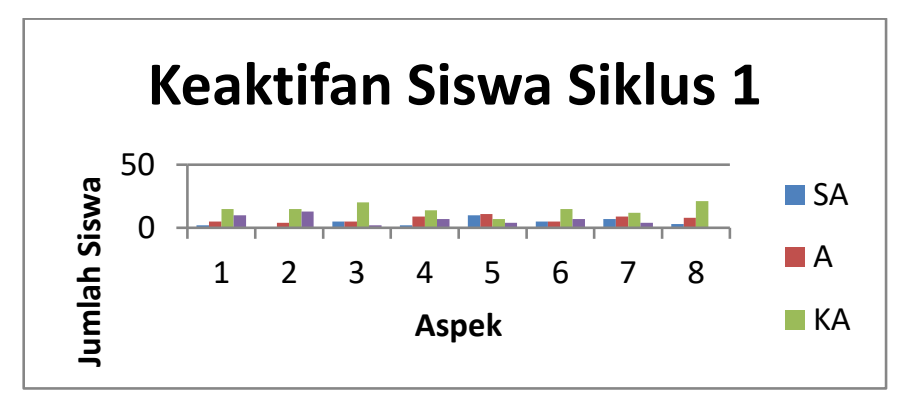

Grafik 3. Perbandingan kondisi pada siklus 1

Dari hasil tersebut dapat dilihat bahwa:

1. Keseriusan siswa $: \mathrm{SA}=2$ Siswa $(6,25 \%), A=5$ siswa $(15,63 \%)$, $\mathrm{KA}=15$ Siswa $(46,87 \%), \mathrm{TA}=10$ Siswa $(31,25 \%)$

2. Inisiatif bertanya siswa : $\mathrm{SA}=$ tidak ada $(0 \%), \mathrm{A}=4$ siswa $(12,5 \%), K A=15$ Siswa $(46,87 \%), T A=13$ Siswa $(40,63 \%)$

3. Partisipasi siswa dalam pembelajaran: $\mathrm{SA}=5$ siswa $(15,63 \%)$, $A=5$ siswa $(15,63 \%), K A=20$ Siswa $(62,5 \%), T A=2$ Siswa $(6,25 \%)$ 
4. Kemampuan siswamenjelaskan konsep dengan kata-kata sendiri $: \mathrm{SA}=2$ siswa $(6,25 \%), \mathrm{A}=9$ siswa $(28,12 \%), \mathrm{KA}=14$ Siswa $(43,75 \%), \mathrm{TA}=7$ Siswa $(21,88 \%)$

5. Berdiskusi : $\mathrm{SA}=10$ siswa $(31,25 \%), \mathrm{A}=11$ siswa $(34,38 \%)$, $\mathrm{KA}=7$ Siswa $(21,87 \%), \mathrm{TA}=4$ Siswa $(12,5 \%)$

6. Kemampuan siswa memahami perintah guru : $\mathrm{SA}=5$ siswa $(15,63 \%), A=5$ siswa $(15,63 \%), K A=15$ Siswa $(46,87 \%), T A=$ 7 Siswa $(21,87 \%)$

7. Kemampuan siswa menyimak cerita dari teman : $\mathrm{SA}=7$ siswa $(21,87 \%), A=9$ siswa $(28,13 \%), K A=12$ Siswa $(37,5 \%), \mathrm{TA}=$ 4 Siswa $(12,5 \%)$

8. Kemampuan siswa membuat catatan penting : $\mathrm{SA}=3$ siswa $(9,37 \%), A=8$ siswa $(25 \%), K A=21$ Siswa $(65,63 \%), T A=0$ Siswa $(0 \%)$

Skor keaktifan siklus 1 secara keseluruhan adalah 57,52 \% dan ini masuk dalam kategori kurang aktif.

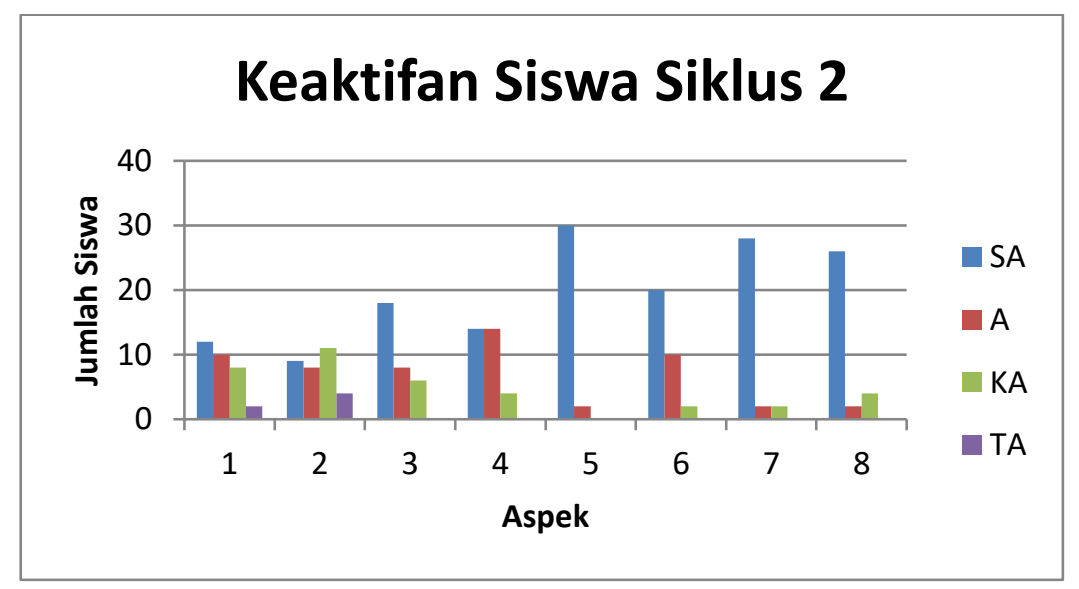

Grafik 4. Perbandingan kondisi pada siklus 2

Dari hasil tersebut dapat dilihat bahwa:

1. Keseriusan siswa $: \mathrm{SA}=12$ Siswa $(3,75 \%), \mathrm{A}=10$ siswa $(31,25 \%), \mathrm{KA}=8$ Siswa $(25 \%), \mathrm{TA}=2$ Siswa $(6,25 \%)$ 
2. Inisiatif bertanya siswa $: \mathrm{SA}=9$ Siswa $(28,12 \%), \mathrm{A}=8$ siswa $(25 \%), K A=11$ Siswa $(34,38 \%), T A=4$ Siswa $(12,5 \%)$

3. Partisipasi siswa dalam pembelajaran: $\mathrm{SA}=18$ siswa (56,25\%), $A=8$ siswa $(25 \%), K A=6$ Siswa $(18,75 \%), T A=0$ Siswa $(0 \%)$

4. Kemampuan siswa menjelaskan konsep dengan kata-kata sendiri $: \mathrm{SA}=14$ siswa $(43,75 \%), \mathrm{A}=14$ siswa $(43,75 \%), \mathrm{KA}=$ 4 Siswa $(12,5 \%), T A=0$ Siswa $(0 \%)$

5. Berdiskusi : $\mathrm{SA}=30$ siswa $(93,75 \%), \mathrm{A}=2$ siswa $(6,25 \%), \mathrm{KA}$ $=0$ Siswa $(0 \%), \mathrm{TA}=0$ Siswa $(0 \%)$

6. Kemampuan siswa memahami perintah guru : $\mathrm{SA}=20$ siswa $(62,5 \%), A=10$ siswa $(31,25 \%), K A=2$ Siswa $(6,25 \%), T A=0$ Siswa $(0 \%)$

7. Kemampuan siswa menyimak cerita dari teman : $\mathrm{SA}=28$ siswa $(87,5 \%), A=2$ siswa $(6,25 \%), K A=2$ Siswa $(6,25 \%)$, TA $=0$ Siswa $(0 \%)$

8. Kemampuan siswa membuat catatan penting : $\mathrm{SA}=26$ siswa $(81,25 \%), A=2$ siswa $(6,25 \%), K A=4$ Siswa $(12,5 \%), T A=0$ Siswa $(0 \%)$

Skor keaktifan siklus 2 secara keseluruhan adalah 85,55 \% dan ini masuk dalam kategori sangat aktif. Keaktifan siswa pada siklus ini sudah sangat tinggi.

Dapat disimpulkan bahwa pembelajaran model cooperative script dari setiap siklusnya mengalami peningkatan hasil belajar dan keaktifan siswa. Kondisi sebelumnya mayoritas minat, keaktifan dan hasil belajar siswa untuk belajar IPS rendah, setelah diterapkan pembelajaran model cooperativs scipt, maka telah terjadi peningkatan yang signifikan. 
JIPSINDO No. 2, Volume 6, September 2019

\section{Refleksi I}

Refleksi I membahas pelaksanaan siklus I, dengan penemuan sebagai berikut :

1. Siswa awal sedikit tegang dimungkinkan karena suasana baru, namun setelah beberapa saat dapat menyesuaikan keadaan.

2. Siswa belum terbiasa belajar dengan mencari atau menghafal materi dan cara menyampaikan pada kawan.

3. Perlengkapan kurang memadai penjelasan guru hanya melalui laptop tidak ditambah lcd. Hal ini dikarenakan berbenturan dengan kegiatan sekolah persiapan kelas IX untuk menghadapi UAN.

4. Pada umumnya siswa merasa senang dengan metode ini.

Dari hasil refleksi I maka kelemahan-kelemahan yang ditemukan selama siklus I, akan diperbaiki pada sikllus II.

\section{Siklus II.}

Tindakan pada Siklus II.

1. Perlengkapan pembelajaran sudah dipersiapkan guru untuk memperjelas penyampaian materi.

2. Banyak yang kurang waktu untuk menyerap materi, karena materi cukup luas.

Dengan adanya peningkatan hasil belajar yang begitu signifikan setelah penerapan metode cooperative script menunjukan bahwa metode ini sangat cocok untuk materi Proses persiapan kemerdekaan Indonesia. Hal ini ditunjukan pada hasil sebelum pre tes dan post tes siswa, yakni pada siklus 2 menunjukan pada posisi diatas 50\% siswa diatas nilai 76 . 
Dari data hasil observasi, yaitu dengan menggunakan 2 orang sebagai observer ditunjukkan bahwa selama proses belajar mengajar berlangsung, pembelajaran model cooperative script siswa lebih aktif dari pembelajaran sebelumnya, yakni pada kedua siklus menunjukan pada posisi kurang aktif dan sangat aktif. Pada metode ini semua siswa aktif berdiskusi mempelajari materi yang akan di ceritakan pada temantemannya. Keberhasilan penggunaan metode ini sangat tergantung pada keaktifan siswa dalam mengembangkan potensi dan kreativitasnya pada saat kegiatan. Oleh karena itu peran guru juga penting, yaitu untuk menumbuhkan dan memberikan motivasi agar siswa melakukan aktivitas belajar dengan baik.

\section{Simpulan}

1. Dengan penerapan metode cooperative script pada mata pelajaran IPS materi Seputar Proklamasi Kemerdekaan Indonesia dapat meningkatkan keaktifan, minat dan motivasi siswa dalam belajar karena siswa terlibat langsung dalam proses penanaman konsep secara mandiri dengan bimbingan guru. Ini terbukti pada hasil penelitian Skor keaktifan pra siklus secara keseluruhan adalah 49,61\% dan ini masuk dalam kategori kurang aktif. Skor keaktifan siklus 1 secara keseluruhan adalah 57,52 \%. Keaktifan siklus 2 secara keseluruhan adalah 85,55 \% dan ini masuk dalam kategori sangat aktif.

2. Model pembelajaran dengan metode cooperative script lebih efektif dalam pencapaian hasil belajar, terbukti hasil pelakasanaannya yang Pada kondisi awal hasil belajar siswa rendah, yang belum mencapai KKM 30 (93.75\%) 
siswa, setelah dilakukan PTK terjadi peningkatan siswa yang mencapai KKM sebanyak 17 (53.12\%) siswa.

3. Metode cooperative script baik diterapkan dalam mata pelajaran IPS khususnya materi Sejarah. Dengan metode ini maka keaktifan siswa dalam mempelajari pelajaran IPS khusunya sejarah lebih termotivasi berlomba mencari informasi serta menghafal materi sehingga siswa lebih paham yang pada akhirnya dapat meningkatkan prestasi belajar.

\section{Daftar Pustaka}

Susilo.(2007). Penelitian Tindakan Kelas. Yogyakarta: Pustaka Book Publisher

Pardjono, dkk. (2007). Penelitian Tindakan Kelas. Yogyakarta: Lembaga Penelitian UNY

Bobbi DePorter, Mark Reardon, dan Sarah Singer-nouri. (2002). Quantum Teaching. Bandung: Kaifa

Suyanto dan Djihad Hisyam.(2000). Refleksi Dan Reformasi Pendidikan Di Indonesia Memasuki Milenium III, Yogyakarta: Adicita Karya Nusa.

Departemen Pendidikan Nasional.(2007).Naskah Akademik Kajian kebijakan Kurikulum Mata Pelajaran Ilmu Pengetahuan Sosial. Jakarta: Badan Penelitian dan Pengembangan Pusat Kurikulum.

Kementrian Pendidikan Nasional (2010). Sejarah Perkembangan Kurikulum SMP. Jakarta: Direktorat Pembina Sekolah Menengah Pertama.

http://nadhirin.blogspot.com/2008/08/metode-pembelajaranefektif.html di akses tanggal 26 April 2011 